\title{
Възможности за лечение на вътрешното ухо
}

\author{
Д. Попова, С. Върбанова \\ Катедра по УНГ-болести при \\ УМБАЛ „Царица Йоанна - ИСУЛ“; МУ - София
}

\begin{abstract}
Резюме
Целта на статията е да се направи обзор на тенденциите и бъдещите възможности за лечение на звукоприемното намаление на слуха. Голяма част от глухотата се дължи на загуба на епителните клетки на вътрешното ухо и невроните на спиралния ганглий. Характерно е за бозайниците, че нямат възможност за регенерация. В момента две са основните възможности за лечение на глухотата и звукоприемното намаление на слуха, а именно слуховите апарати и кохлеарната имплантация. За да се намери начинът за лечение, е необходимо и добре да се знае и механизмът на слуховата увреда. Три са основните стратегии: да се индуцира пролиферацията на подпорни клетки чрез интерфериране на клетъчния цикъл на регулация. Трансдиференция на подпорни клетки в слухови чрез генно инженерство. Трансплантация на стволовите клетки, които да заменят изгубените слухови клетки. Възможността за директно поставяне на стволови клетки и вектори във вътрешното ухо от страната на лезията, повишаване на пролиферацията на подпорните клетки и последващата им диференциация са бъдещето на лечението на звукоприемната слухова загуба.
\end{abstract}

\section{Abstract}

THE AIM of this paper has been to provide an overview of advances in the study of the future trends and treatment of sensorineural hearing loss. Most of deafness have a neuro-sensory origin and are characterized by a loss of hair cells and auditory neurons in the spiral ganglion. Hair cells in mammalian systems do not have the capacity to regenerate. At the moment, hearing aids and CI's are the only treatment available. Strategies to restore sensorineural hearing loss focus on the replacement of lost hair cells, but two exciting lines of research hold promise in restoring inner ear function. To restore hearing in a patient suffering from deafness, it is necessary to study the mechanisms of the dead of hearing cells and the pathways who $t$ might lead to the regeneration of neurosensory structures of the inner ear.

HAIR CELL REGENERATION: The production of hair cells and supporting cells is terminated during embryonic development of the cochlea in mammals. However, several recent arguments suggest that new hair cells can be produced by the sensory epithelium.
B ъзможностите за регенерация на вътрешното ухо се базират на идеята за индуциране на регенеративните способности на увредената или унищожена тъкан от останалата тъкан. Следващата насока е трансплантация на клетки in vivo или ex vivo. Индуцирането на ендогенната регенерация на вътрешното ухо се базира на резидуалните тъкани. Проведени са опити върху бозайници и гръбначни животни, например птици, които демонстрират изключителни регенеративни способности.

Увредата на слуха се дължи в повечето случаи на увреда на слуховите клетки на сензорния епител на вътрешното ухо. Тези клетки са много чувствителни на увреди от страна на болести, шум, ототоксични лекарства, възраст, както и генетична предиспозиция. За съжаление при човека и други бозайници при загуба на слуховите клетки последните не се заместват с друга тъкан. Загубата на слуховите клетки и последващата функционална депривация е перманентна и невъзвратима. При птиците основните принципи на регенерация на слуховите клетки се основават на пролиферация и конверсия. При увреда на слухови клетки от екзогенен причинител настьпва пролиферация на подпорните клетки на вътрешното ухо, новите слухови клетки подлежат на директна трансформация и трансдиференциация в нови слухови клетки. Тези нови клетки се свързват със здравите оцелели неврони. По този начин се осъществява функционално заместване, тези способности бозайниците не притежават.

При опитите за регенерация на слухови клетки при бозайници се проследяват три основни стратегии: 
NEURONAL REGENERATION: The specific genes and growth factors induce the survival of auditory neurons in vitro and in vivo. These molecules can be administered locally in the inner. The advances in otobiology and surgery will, in the future, be combined to devise new and innovative treatments for inner ear disorders.

IN CONCLUSION: Recent studies on the regeneration of neurosensory structures of the inner ear suggest that eventually it will be possible to replace the hair cells in the cochlea of mammals and to reinnervate them by auditory neurons in order to restore hearing in patients suffering from deafness
1. Да се индуцира пролиферацията на подпорни клетки чрез интерфериране на клетъчния цикъл на регулация.

2. Трансдиференция на подпорни клетки в слухови чрез генно инженерство.

3. Трансплантация на стволовите клетки, които да заменят изгубените слухови клетки.

При регулация на клетъчния цикъл, основните проблеми са индукцията на клетъчното деление от подпорните клетки (които сами по себе си притежават такива възможности), при пълна слухова загуба настьпва пълна загуба на епителните клетки на слуховия анализатор. Поради тези промени е необходимо да се проследи и изследва регулацията на клетъчния цикъл на инхибиране в Кортиевия орган и да се открият молекулите, отговорни за крайната диференциация на епителните клетки. На този етап са открити участници в инхибиторния процес на р27Kip1 в подпорните клетки на Кортиевия орган. Делеция на р27Kip1 променя пролиферативните възможности, като позволява клетъчно деление по време на ембрионалния период вместо крайна митоза и по този начин позволява деление на клетката при възрастни индивиди (in vivo). Повишаването способността за пролиферация се увеличава благодарение на намалената регулация от страна на cyclin-depanding киназен инхибитор pE7. Теоретично това е една от възможностите за регенерация на слуховите клетки.

Tрансдиференциация: Диференциацията на ниво на слуховите клетки е независима и е възможно участието на допълнителна молекула. По време на ембрионалното развитие след последната митоза се индуцира диференциацията на слуховите клетки, по време на този процес е открит и генът Math 1. Този ген е фактор на транскрипцията, който се явява като позитивен регулатор на клетьчната диференциация. При делеция на Math 1 се предотвратява диференциацията на слуховите клетки в сензорен епител. При свръхсекреция на Math 1 (in vitro и in vivo) при екзогенна плазмена трансфекция се променя поколението на нови слухови клетки. Този механизъм би могъл да се ползва при конверсия на подпорни в слухови клетки, при загуба на слуховите клетки.

Трансплантация на стволови клетки. Стволовите клетки имат възможността да пролиферират и да се диференцират в различни видове клетки. Естествен е въпросът за използването им при пълна загуба на сетивните клетки на Кортиевия орган. Различни типове ембрионални стволови клетки могат директно да се трансплантират в средното ухо. Те са получени от ембриони и се диференцират във възрастови клетки, които пролиферират и обхващат тьканта на гостоприемника. Проблемът е, че диференциацията на стволовите клетки е неподходяща и е необходимо да се пре- 
върнат в необходимите епителни клетки на кохлеата. Това налага да се идентифицират сигналните пътища и да се определи факторьт на клетьчната диференциация, и то в необходимите клетки.

Разбирането на патологичните пътища, водещи до загиването на слуховите клетки във вътрешното ухо и тяхната регенерация, геномът на вътрешното ухо, генната терапия с участието на вирусни медиатори и технологията на стволовите клетки са първите стъпки при лечението на звукоприемното намаление на слуха. За да се достигне идеална-

\section{Литература:}

1. Steel K, Kros C. A genetic approach to understanding auditory function. Nat Genet 2001; 27: 143-149.

2. Verma IM, Somia N. Gene therapy - promises, problems and prospects. Nature 1997; 389: 239-242.

3. Kawamoto $\mathrm{K}$ et al. Hearing and hair cells are protected by adenoviral gene therapy with TGF-B1 and GDNF. Mol Ther 2003; 7: 484-492. та генна терапия, е необходимо да се използват различните методи, като вирулентността и стабилността на вирусните вектори от една страна, от друга - стабилността на липозомите. Възможността за директно поставяне на стволови клетки и вектори във вътрешното ухо, от страната на лезията, повишаване на пролиферацията на подпорните клетки и последващата им диференциация са бъдещето на лечението на звукоприемната слухова загуба.
4. Thomas CE, Ehrhardt A, Kay MA. Progress and problems with the use of viral vectors for gene therapy. Nat Genet Rev 2003; 4: 346-358.

5. Blair E. Adenoviral vectors, breaking a barrier to gene therapy? Gene therapy 2004; 11: 229-230.

6. Lalwani AK, Mhatre AN. Cochlear gene therapy. Ear Hearing 2004; 24: $342-348$. 